\title{
Antioxidants and molecular damage in Nile Tilapia (Oreochromis niloticus) after exposure to microplastics
}

\author{
Mohamed Hamed $^{1}$ • Hamdy A. M. Soliman ${ }^{2}$ - Alaa G. M. Osman ${ }^{1}$ - Alaa El-Din H. Sayed ${ }^{3}$ \\ Received: 15 October 2019 / Accepted: 27 January 2020 / Published online: 11 February 2020 \\ (C) The Author(s) 2020
}

\begin{abstract}
Recently, research on the biological effects of microplastics (MPs) has grown exponentially. However, effects of MPs on freshwater fishes and the mechanisms of the biological effects of MPs were limited. So, the purpose of the current study was to clarify the effects of microplastics on oxidative stress response, DNA fragmentation, and proteinogram of the early juvenile stage of Nile Tilapia (Oreochromis niloticus). The fishes were assigned into four groups: one control, three MPs-exposed groups as $1 \mathrm{mg} / \mathrm{L}$ of MPs, $10 \mathrm{mg} / \mathrm{L}$ of MPs, and $100 \mathrm{mg} / \mathrm{L}$ of MPs respectively for 15 days and 15 days of recovery. The activities of superoxide dismutase, catalase, total peroxides, and oxidative stress index (OSI), as well as lipid peroxidation and DNA fragmentation, increased in groups exposed to MPs compared to the control group in a dose-dependent manner. In contrast, the activity of total antioxidant capacity decreased in groups exposed to MPs compared to the control group in a dose-dependent manner. The electrophoretic pattern of muscle proteins revealed alteration in the proteinogram in the MPs-exposed groups compared to control. After the recovery period, the activities of superoxide dismutase, catalase, total peroxides, total antioxidant capacity, lipid peroxidation, DNA fragmentation, and the electrophoretic pattern of muscle proteins returned to normal levels in $1 \mathrm{mg} / \mathrm{L}$ of MPs-exposed group. Combined with our previous work, these results suggest that MPs cause the overproduction of reactive oxygen species (ROS) and alters the antioxidants parameters, resulting in oxidative stress and DNA damage. The present study fosters a better understanding of the toxic effects of MPs on Tilapia as a freshwater model.
\end{abstract}

Keywords Microplastics $\cdot$ Nile tilapia $\cdot$ Malondialdehyde $\cdot$ DNA damage $\cdot$ SDS-PAGE

\section{Introduction}

Highlights

- Microplastics (MPs) were induced antioxidant alterations in tilapia early juvenile.

- DNA damage was reported in the tilapia after exposure to microplastics (MPs)

- The effect of microplastics (MPs) was recoverable in concentrationdependent.

Responsible editor: Philippe Garrigues

Alaa El-Din H. Sayed

alaasayed@aun.edu.eg; alaa_h254@yahoo.com

1 Department of Zoology, Faculty of Science, Al-AzharUniversity (Assiut Branch), Assiut 71524, Egypt

2 Department of Zoology, Faculty of Science, Sohag University, Sohag 8562, Egypt

3 Department of Zoology, Faculty of Science, Assiut University, Assiut 71516, Egypt
Recently, there is increasing sensibility of the harmful effects of microplastics due to their extensive use in commercial, industrial, and medicinal applications (Lusher et al. 2017). It is known that exposure of fish to different pollutants in the water ecosystem can prompt the surfeit of reactive oxygen species (ROS) which causes harmful effects to macromolecules of cells (Sureda et al. 2006) because microplastics can be digested by fish and causes some effects (de Sá et al. 2018; Jovanovic 2017). The fish have an intricate antioxidant system which comprises superoxide dismutase (SOD), catalase (CAT), glutathione S-transferase (GST), and glutathione peroxidase (GPx), which encounter the oxidative damage of reactive oxygen species (ROS) (Sayed and Soliman 2018; Soliman et al. 2019). Oxidative stress index (OSI) is a comparative indicator illustrating the interaction among the freeradical inducing agents and their antioxidants system (Fazio et al. 2015; Sayed and Abul Khalil 2016). Malondialdehyde (MDA) is regarded as a bioindicator of the lipid peroxidation 
(LPO) (Karami et al. 2016). The induction of antioxidant enzymes and the elevation of the lipid peroxidation in fish exposed to different pollutants can be regarded as bioindicators of oxidative stress (Karami et al. 2016). Microplastics may induce oxidative stress by different mechanisms as stimulating some intracellular signal transduction pathways as in Brachionus koreanus (Jeong et al. 2016) and zebrafish (Danio rerio) (Lu et al. 2016), activation of catalase in sheepshead minnows (Cyprinodon variegatus) (Choi et al. 2018), elevation of brain lipid peroxidation (LPO) levels in juveniles of the European bass (Dicentrarchus labrax) (Barboza et al. 2018), suppression of antioxidant enzymes in juvenile of the Chinese mitten crab (Eriocheir sinensis) (Yu et al. 2018), decline the catalase levels and the glutathione content in zebrafish larvae (Wan et al. 2019), induction of superoxide dismutase (SOD) levels in liver of red tilapia (Oreochromis niloticus) (Ding et al. 2018; Zhang et al. 2018), and the upregulation of superoxide dismutase (SOD) and catalase (CAT) levels in the gut of the zebrafish (Qiao et al. 2019).

DNA fragmentation assay is regarded as a valuable method to evaluate the genotoxicity of any pollutant in the environment (Frenzilli et al. 2009; Nacci et al. 1996). Microplastics have been reported to induce DNA fragmentation in mussels (Mytilus galloprovincialis) (Avio et al. 2015; Pittura et al. 2018; Revel et al. 2019), Scrobicularia plana (Ribeiro et al. 2017), and Neocaridina davidi (Berber 2019), and the intestinal cell line (Bussolaro et al. 2019).

The electrophoretic techniques (e.g., SDS-PAGE) are promising tools for identifying protein profile in response to stress and sublethal level of different pollutants (Muhammad et al. 2018; Paruruckumani et al. 2015a).

The Nile Tilapia (Oreochromis niloticus) is an African freshwater cichlid and one of the world's most important food fishes (Soliman 2017). So, the present study aimed to examine the effects of microplastics on oxidative stress response, DNA fragmentation, and proteinogram of the popular fish (Oreochromis niloticus) early juvenile.

\section{Materials and methods}

\section{Microplastics}

Microplastics (with $>90 \%$ of microplastics $>100 \mathrm{~nm}$ in size) purchased from Toxemerge Pty Ltd., Australia).

\section{Fish exposure}

Tilapia (Oreochromis niloticus) early juvenile (weight $4.35 \pm$ 0.067 , length $3.28 \pm 0.12$ ) were obtained from Aquaponics unit (Al Azhar University) and transported to the Fish Biology Laboratory. The physicochemical properties of test water (conductivity $260.8 \mu \mathrm{M} \mathrm{cm}^{-1}$, pH 7.4, dissolved oxygen $6.9 \mathrm{mg} \mathrm{L}^{-1}$, temperature $28.5^{\circ} \mathrm{C}$, photoperiod $12: 12$ light:dark). Four groups of fishes (30 fish per each) were used: one control, three MPs-exposed groups as $1 \mathrm{mg} / \mathrm{L}$ of MPs, $10 \mathrm{mg} / \mathrm{L}$ of MPs, and $100 \mathrm{mg} / \mathrm{L}$ of MPs respectively for 15 days and 15 days of recovery according to Katzenberger and Thorpe (2015). At the end of the experiment, six fish from each group were randomly chosen and benumbed using ice to lessen the stress owing to processing. Blood was collected from the caudal vein for antioxidant enzymes and lipid peroxidation measurements as well as liver tissue for DNA fragmentation assay and muscle tissue for SDS-PAGE.

\section{Measurement of antioxidants biomarkers}

Antioxidants kits were purchased from Biodiagnostic Company, Cairo, Egypt. The MPs stock solution was prepared according to (Hamed et al. 2019). Superoxide dismutase (SOD) was measured based on its ability to inhibit the phenazine methosulphate-mediated reduction of nitroblue tetrazolium dye to form a red product (Nishikimi et al. 1972). Catalase (CAT) was determined based on the fact that 3,5-dichloro-2hydroxybenzene sulfonic acid could rapidly terminate the degradation reaction of hydrogen peroxide catalyzed by CAT and react with the residual hydrogen peroxide to generate a yellow product (Aebi 1984). Total antioxidant capacity (TAC) was measured according to protocol given by (Koracevic et al. 2001). Total peroxide (TPX) was assessed following the procedure of (Harma et al. 2005) and calculated from the standard curve constructed using standard concentrations.

\section{Plasma oxidative stress index, lipid peroxidation, and DNA fragmentation}

It is the percentage ratio of TPX content to TAC concentration, and measured according to the following equation (Harma et al. 2005): OSI $=(\mathrm{TPX}, \mu \mathrm{M} / \mathrm{L}) /(\mathrm{TAC}, \mu \mathrm{M} / \mathrm{L}) \times 100$.

Malondialdehyde (MDA) was measured according to the thiobarbituric acid reaction (Ohkawa et al. 1979). Three hundred milligrams of liver tissue was stored at $80^{\circ} \mathrm{C}$ for measurement of DNA fragmentation according to Mekkawy et al. (2010). Tissues were homogenized in cold phosphate buffer saline (0.1 M; pH 7.4) using a Pottere Elvejhem glass/Teflon homogenizer. Thereafter, homogenates filtration and centrifugation were performed $\left(10 \mathrm{~min}\right.$ at $\left.4{ }^{\circ} \mathrm{C} ; 1600 \mathrm{rpm}\right)$. DNA fragmentation was determined based on (Kurita-Ochiai et al. 1999).

\section{SDS-PAGE technique}

Portions of muscles ( $\sim 0.1 \mathrm{~g}$ fresh weight) of each fish were suspended in $1.0 \mathrm{ml}$ lysing buffer, heated at $100{ }^{\circ} \mathrm{C}$ for $5 \mathrm{~min}$, centrifuged at $10,000 \mathrm{rpm}$ for $30 \mathrm{~min}$, and $50 \mu \mathrm{L}$ of extracted protein in each treatment was used for protein analysis using SDS-PAGE according to (Laemmli 1970) in the first 
dimension. The low molecular weight standards (BioBasic, USA) were run concurrently. The protein molecular mass and densitometric analysis of protein bands were determined using Gel-Pro Analyzer package V3.1 for Windows XP/NT (Media Cybernetica 1993-97).

\section{Statistical analysis}

All data were analyzed using the SPSS package (SPSS 1998) at the 0.05 significance level. Data were tested for normality (Shapiro-Wilk test) and our data were normal. Then, data were tested for homogeneity of variances (Levene's test) using oneway analysis of variance (ANOVA). In the case of variance equality, Fisher's LSD post hoc test was used to compare treated groups against control. In cases of variance inequality, Dunnett's post hoc test was used to compare treated groups against control.

\section{Ethical statement}

Experimental setup and fish handling were approved by the Research, Ethical Committee of the Faculty of Science, Assuit University, Assuit, Egypt.

\section{Results}

\section{Antioxidants biomarkers}

The activities of superoxide dismutase (SOD), catalase (CAT), total peroxides (TPX), malondialdehyde (MDA), and oxidative stress index (OSI) showed significant increase $(P<0.05)$ after exposure to 1,10 , and $100 \mathrm{mg} / \mathrm{L}$ of microplastics for 15 days compared to the control group (Table 1). On the other hand, the activity of total antioxidant capacity (TAC) displayed a significant decrease $(P<0.05)$ after exposure to 1,10 and $100 \mathrm{mg} / \mathrm{L}$ of microplastics for 15 days (Table 1).
After the recovery period, the activities of superoxide dismutase (SOD), catalase (CAT), total peroxides (TPX), malondialdehyde (MDA), and total antioxidant capacity (TAC) returned to normal levels in $1 \mathrm{mg} / \mathrm{L}$ of MPs-exposed group. While oxidative stress index (OSI) did not recover to normal levels in all MPs-exposed groups (Table 1).

\section{Lipid peroxidation and DNA fragmentation}

Lipid peroxidation and DNA fragmentation showed significant increase $(P<0.05)$ after exposure to 1,10 , and $100 \mathrm{mg} / \mathrm{L}$ of microplastics for 15 days compared to the control group (Figs. 1 and 2). After the recovery period, lipid peroxidation and DNA fragmentation returned to normal levels in $1 \mathrm{mg} / \mathrm{L}$ of MPs-exposed group (Figs. 1 and 2).

\section{The electrophoretic pattern of muscle proteins}

The electrophoretic pattern showed that the total number of muscle protein bands in control group was 8 bands (Table 2 and Fig. 3). The number of protein bands decreased to 7 and 5 in muscle after exposure to 1,10 , and $100 \mathrm{mg} / \mathrm{L}$ of microplastics for 15 days, respectively (Table 2 and Fig. 3). After the recovery period, the total number of muscle protein bands returned to normal levels in $1 \mathrm{mg} / \mathrm{L}$ of MPs-exposed group (Table 2 and Fig. 3).

\section{Discussion}

Antioxidant biomarkers were used to detect various environmental stressors effects in some aquatic organisms (Hook et al. 2014). In the present study, the activities of superoxide dismutase (SOD), catalase (CAT), total peroxides (TPX), malondialdehyde (MDA), DNA fragmentation, and oxidative stress index (OSI) showed a significant increase while the activity of total antioxidant capacity (TAC) showed a

Table 1 Effect of microplastics (MPs) exposure and recovery for 15 days on antioxidants enzymes of the tilapia (Oreochromis niloticus) early juvenile

\begin{tabular}{|c|c|c|c|c|c|c|c|c|}
\hline \multirow[t]{3}{*}{ Biomarkers } & \multicolumn{8}{|l|}{ Groups } \\
\hline & \multicolumn{4}{|c|}{ Exposure period } & \multicolumn{4}{|c|}{ Recovery period } \\
\hline & Control & $\begin{array}{l}1 \mathrm{mg} / \mathrm{L} \\
\text { of MPs }\end{array}$ & $\begin{array}{l}10 \mathrm{mg} / \mathrm{L} \\
\text { of MPs }\end{array}$ & $\begin{array}{l}100 \mathrm{mg} / \mathrm{L} \\
\text { of MPs }\end{array}$ & Control & $1 \mathrm{mg} / \mathrm{L}$ of MPs & $10 \mathrm{mg} / \mathrm{L}$ of MPs & $100 \mathrm{mg} / \mathrm{L}$ of MPs \\
\hline SOD (IU/L) & $11.01 \pm 0.11^{\mathrm{a}}$ & $11.62 \pm 0.07^{\mathrm{b}}$ & $11.88 \pm 0.04^{\mathrm{b}}$ & $11.95 \pm 0.02^{\mathrm{b}}$ & $10.35 \pm 0.03^{\mathrm{a}}$ & $11.50 \pm 0.07^{\mathrm{ab}}$ & $11.74 \pm 0.03^{\mathrm{bc}}$ & $11.87 \pm 0.01^{\mathrm{c}}$ \\
\hline CAT (IU/L) & $10.23 \pm 0.11^{\mathrm{a}}$ & $10.72 \pm 0.06^{\mathrm{ab}}$ & $10.83 \pm 0.04^{\mathrm{bc}}$ & $11.03 \pm 0.04^{\mathrm{c}}$ & $10.23 \pm 0.08^{\mathrm{a}}$ & $10.52 \pm 0.05^{\mathrm{ab}}$ & $10.74 \pm 0.05^{\mathrm{bc}}$ & $10.82 \pm 0.05^{\mathrm{c}}$ \\
\hline $\mathrm{TPX}(\mu \mathrm{M} / \mathrm{L})$ & $1.49 \pm 0.02^{\mathrm{a}}$ & $1.58 \pm 0.01^{\mathrm{ab}}$ & $1.65 \pm 0.01^{\mathrm{bc}}$ & $1.83 \pm 0.05^{\mathrm{c}}$ & $1.44 \pm 0.04^{\mathrm{a}}$ & $1.54 \pm 0.02^{\mathrm{a}}$ & $1.59 \pm 0.02^{\mathrm{ab}}$ & $1.69 \pm 0.03^{\mathrm{b}}$ \\
\hline OSI (\%) & $147.21 \pm 2.86^{\mathrm{a}}$ & $163.72 \pm 2.5^{\mathrm{b}}$ & $179.87 \pm 2.46^{\mathrm{c}}$ & $207.50 \pm 6.11^{\mathrm{d}}$ & $142.88 \pm 4.16^{\mathrm{a}}$ & $153.04 \pm 1.81^{\mathrm{b}}$ & $163.4 \pm 1.85^{\mathrm{c}}$ & $188.33 \pm 2.32^{\mathrm{d}}$ \\
\hline $\mathrm{TAC}(\mu \mathrm{M} / \mathrm{L})$ & $1.01 \pm 0.01^{\mathrm{a}}$ & $0.97 \pm 0.01^{\mathrm{ab}}$ & $0.92 \pm 0.01^{\mathrm{bc}}$ & $0.88 \pm 0.00^{\mathrm{c}}$ & $1.01 \pm 0.00^{\mathrm{a}}$ & $1 \pm 0.00^{\mathrm{a}}$ & $0.97 \pm 0.01^{\mathrm{a}}$ & $0.90 \pm 0.01^{\mathrm{b}}$ \\
\hline
\end{tabular}

Data are represented as mean \pm SE. Values with different superscript letter in the same row for each parameter are significantly different $(P<0.05)$ 
Fig. 1 Lipid peroxidation $(\mathrm{nmol} / \mathrm{ml})$ in tilapia (Oreochromis niloticus) early juvenile after microplastics (MPs) exposure and recovery for 15 days

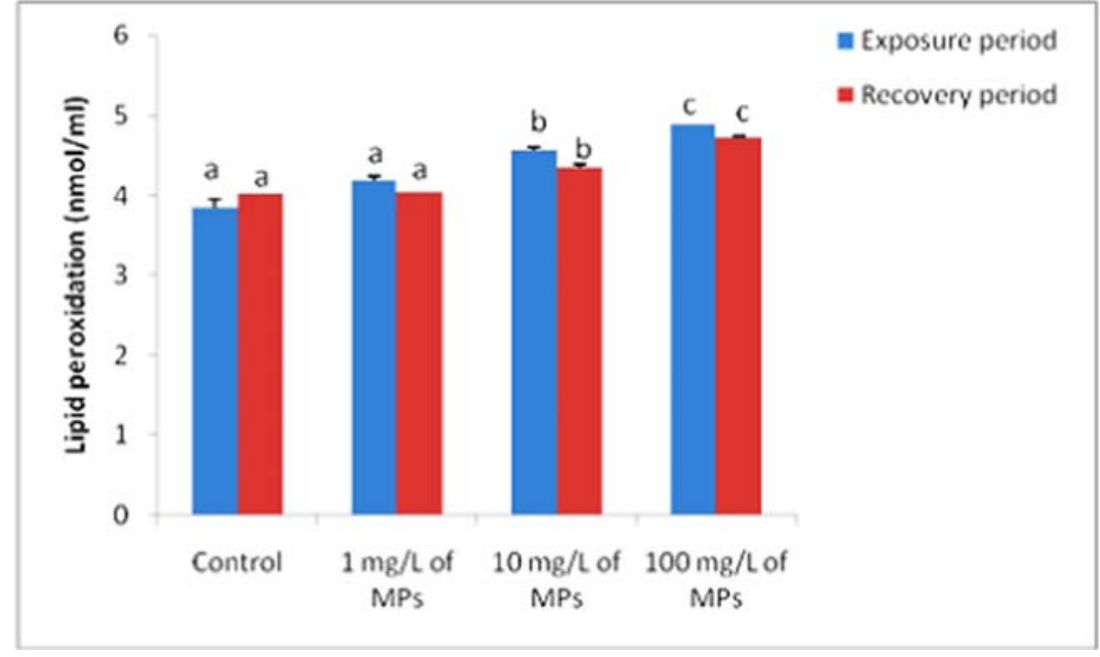

significant decrease after exposure to 1,10 , and $100 \mathrm{mg} / \mathrm{L}$ of microplastics for 15 days compared to the control group. Microplastics that prompted disturbance in antioxidant enzymes have been reported in different aquatic organisms (Prinz and Korez 2020) including early juveniles of the common goby (Pomatoschistus microps) after the concurrent exposure to MP and Cr (VI) (Luis et al. 2015) and monogonont rotifer (Brachionus koreanus) exposed to $10 \mathrm{mg} \mathrm{L}^{-1}$ PS-MPs (Jeong et al. 2016). Moreover, the activity of catalase (CAT) was increased in zebrafish after exposure to 5 - $\mu \mathrm{m}$ polystyrene microplastics (Lu et al. 2016). Similarly, catalase (CAT) activity was induced in sheepshead minnows (Cyprinodon variegatus) exposed to $50 \mathrm{mg} / \mathrm{L}$ irregular microplastics (Choi et al. 2018). Also, Paul-Pont et al. (2016) reported that the activity of SOD was elevated after co-exposure to MPs and fluoranthene in the marine mussels (Mytilus spp.) compared to the single groups (control; FLU and micro-PS). Moreover, activities of SOD increased in red tilapia exposed to $0.1 \mu \mathrm{m}$ PS-MPs (Ding et al. 2018). Furthermore, Qu et al. (2019) observed that the activity of SOD was induced after co- exposure to micro-PS + venlafaxine in the loach (Misgurnus anguillicaudatus). The SOD activities induced in the liver of red tilapia (Oreochromis niloticus) after exposure to polystyrene microplastics (Zhang et al. 2018). In addition, CAT and SOD activities were elevated in the gut of the zebrafish exposed to MPs (Qiao et al. 2019).

Lipid peroxidation levels were induced in juveniles of the marine fish (Pomatoschistus microps) after exposure to PEMPs (Ferreira et al. 2016). Also, the higher LPO levels were observed in the brain of D. labrax juveniles treated with microplastics (Barboza et al. 2018). Furthermore, higher LPO levels were observed in the freshwater bivalve (Corbicula fluminea) treated with microplastics (Oliveira et al. 2018). The oxidative stress and lipid peroxidation may be assigned to either malnutrition or food digestion inhibition due to large-sized MPs that were ingested by the fish (Lu et al. 2016) as well as additives that are commonly incorporated into plastics during manufacture to change their properties or extend the life of the plastic which include endocrinedisrupting chemicals such as polybrominated diphenyl ethers,
Fig. 2 Liver DNA fragmentation (\%) in tilapia (Oreochromis niloticus) early juvenile after microplastics (MPs) exposure and recovery for 15 days

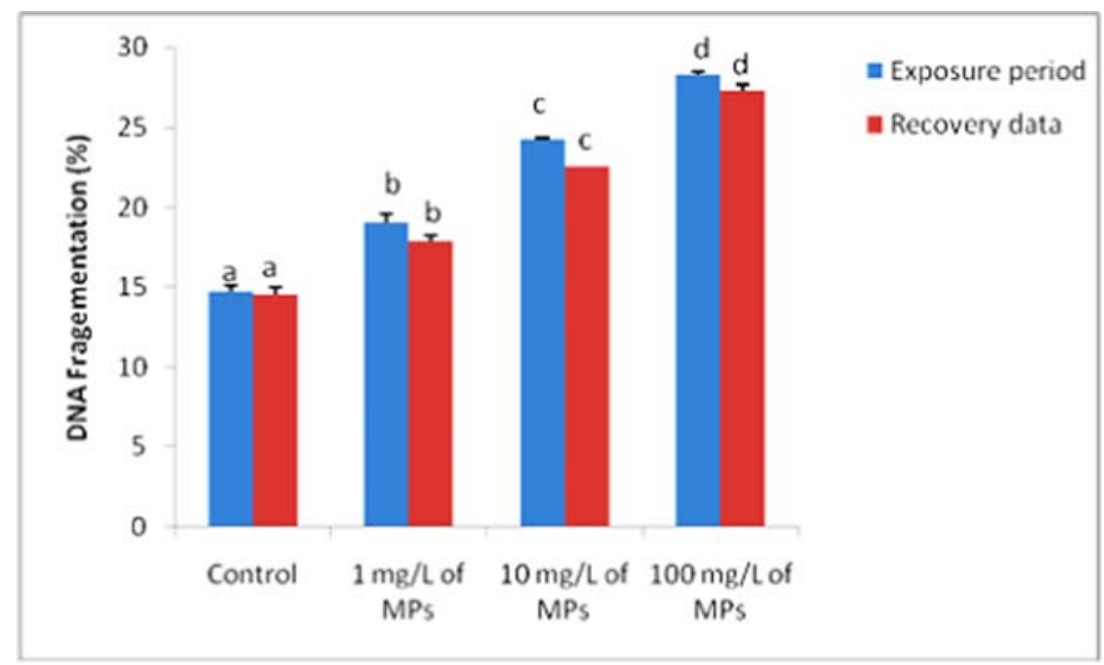


Table 2 Molecular weight (in kda) of muscle proteins of the tilapia (Oreochromis niloticus) early juvenile after microplastics (MPs) exposure and recovery for 15 days

\begin{tabular}{|c|c|c|c|c|c|c|c|c|c|}
\hline \multirow[t]{3}{*}{ Rows } & \multicolumn{9}{|l|}{ Lanes } \\
\hline & \multirow[t]{2}{*}{ Marker } & \multicolumn{4}{|c|}{ Exposure period } & \multicolumn{4}{|c|}{ Recovery period } \\
\hline & & Control & $1 \mathrm{mg} / \mathrm{L}$ of MPs & $10 \mathrm{mg} / \mathrm{L}$ of MPs & $100 \mathrm{mg} / \mathrm{L}$ of MPs & Control & $1 \mathrm{mg} / \mathrm{L}$ of MPs & $10 \mathrm{mg} / \mathrm{L}$ of MPs & $100 \mathrm{mg} / \mathrm{L}$ of MPs \\
\hline $\mathrm{r} 1$ & 233 & & & & & 229 & & & \\
\hline $\mathrm{r} 2$ & & & & & 217 & & & 212 & \\
\hline r3 & & & 207 & 209 & 208 & & 206 & & 206 \\
\hline $\mathrm{r} 4$ & 205 & 204 & & 202 & & 205 & & 202 & \\
\hline $\mathrm{r} 5$ & & 196 & 197 & & 200 & 196 & 198 & 196 & 199 \\
\hline r6 & 186 & & & & & & & & \\
\hline $\mathrm{r} 7$ & 164 & & & & & & 163 & & \\
\hline r8 & & 146 & 147 & 149 & 150 & 145 & 147 & 145 & 146 \\
\hline r9 & 136 & 135 & 135 & & 135 & 133 & 132 & 130 & \\
\hline $\mathrm{r} 10$ & 115 & & & & & & & & \\
\hline r11 & 85 & & & & & & & & \\
\hline $\mathrm{r} 12$ & 67 & & & & & & & & \\
\hline r13 & 52 & 49 & 52 & & & 49 & & & \\
\hline r14 & 34 & 35 & 35 & 34 & & 36 & 32 & 30 & 33 \\
\hline r15 & & 24 & 29 & 25 & 28 & 30 & 26 & 24 & 23 \\
\hline
\end{tabular}

nonylphenol, phthalates, and the constituent monomer bisphenol-A. If these chemicals leach out of the stored plastics, they could potentially affect the physiology of the animal (Katzenberger and Thorpe 2015) and this concept is supported by the first part of this study as hemotoxic effects of MPs (Hamed et al. 2019). Oxidative stress index (OSI) is a comparative indicator illustrating the interaction among the freeradical inducing agents and their antioxidants system (Sayed and Abu Khalil 2016). Oxidative stress index (OSI) induction has been reported in different models as arsenite toxicity in goldfish (Bagnyukova et al. 2007), methyltestosterone effects in Nile Tilapia (Oreochromis niloticus) (Sayed and Abu Khalil 2016).

Fig. 3 Electropherogram of muscle proteins of the tilapia (Oreochromis niloticus) early juvenile after microplastics (MPs) exposure and recovery for 15 days
In contrary to our results, the activity of SOD decreased after co-exposure to Cd and MPs in zebrafish (Lu et al. 2016). In addition, the activity of CAT declined in zebrafish treated with polystyrene microplastics (Wan et al. 2019). This decline in antioxidant enzymes was explained by energy expenditure of oxidative stress in response to microplastic exposition. Moreover, an elevation in TAC was detected in Mytilus galloprovincialis treated with $50 \mathrm{mg} \mathrm{L}^{-1}$ PS (Brandts et al. 2018; Pittura et al. 2018), while it was observed that virgin and contaminated low-density polyethylene did not induce TAC and lipid peroxidation in mussels.

Microplastics have been reported to induce DNA fragmentation in mussels Mytilus galloprovincialis (Avio et al. 2015;

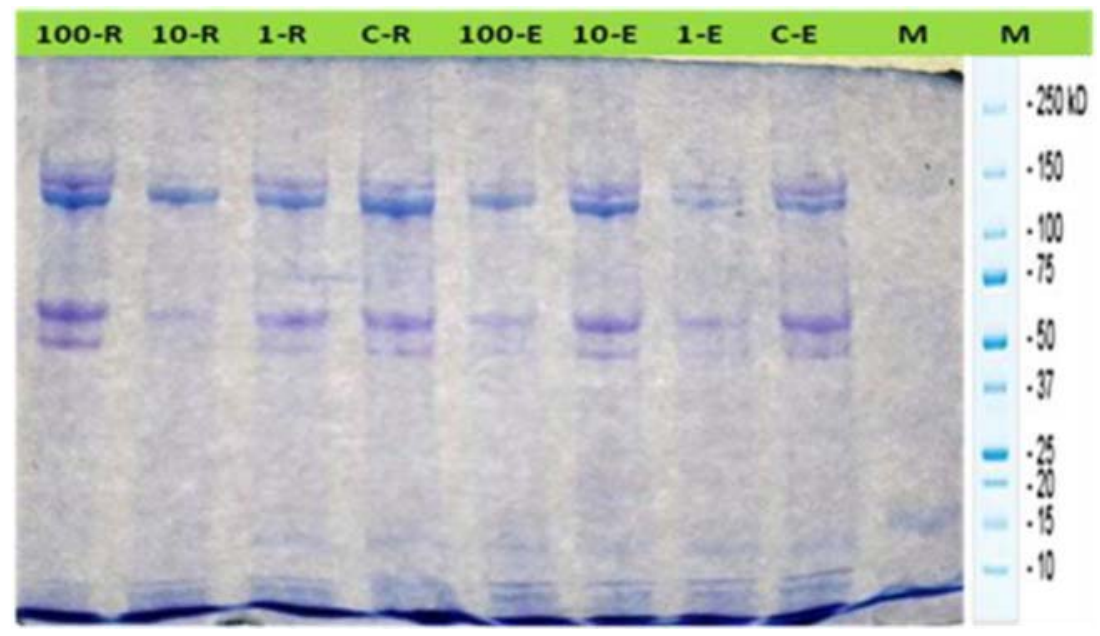


Pittura et al. 2018; Revel et al. 2019), Scrobicularia (Ribeiro et al. 2017), Neocaridina davidi (Berber 2019), and the intestinal cell line (Bussolaro et al. 2019). The genotoxicity of microplastics can be related to either the direct interaction with DNA or indirect mechanism by free radicals overproduction and oxidative stress (Manke et al. 2013). On the other hand, DNA strand break levels remain steady in (Mytilus galloprovincialis) treated with microplastics (Pittura et al. 2018). Also, virgin polystyrene microbeads do not produce genetic damage in freshwater zebra mussel (Dreissena polymorpha) (Magni et al. 2018).

In this study, the electrophoretic pattern showed that total number of muscle protein bands in control group was 8 bands. The number of protein bands decreased to 7 and 5 after exposure to 1,10 , and $100 \mathrm{mg} / \mathrm{L}$ of microplastics for 15 days, respectively. The change in the protein subunit band patterns may be due to change in the turn over (synthesis/degradation) of various proteins (Paruruckumani et al. 2015b). Also, Patterson (1976) reported that the pollutants inhibit protein synthesis through interaction with nucleic acids where our results were matched with this concept. Similar reduction in the number of banding pattern was observed in the muscle and gills of Lates calcarifer after exposure to copper (Paruruckumani et al. 2015b). Some pollutants (e.g., $\mathrm{CuSO}_{4}$, malathion, and paraquat) prompted disappearance of specific blood protein fractions in Oreochromis niloticus (Sharaf-Eldeen and Abdel-Hamid 2002). Tripathi and Shukla (1990) observed alterations in the cytoplasmic protein pattern of fish Clarias batrachus by performing electrophoresis of the cytoplasmic protein fractions of the liver and the skeletal muscle exposed to endosulfan and methyl parathion for 28 days. Badaway and El-Serafy (1998) reported that Clarias gariepinus collected from different polluted water bodies showed disappearance of specific serum protein fractions and others were polymorphic.

In the present study, after the recovery period, the activities of superoxide dismutase (SOD), catalase (CAT), total peroxides (TPX), total antioxidant capacity (TAC), malondialdehyde (MDA), DNA fragmentation, and the electrophoretic pattern of muscle proteins returned to normal levels in $1 \mathrm{mg} / \mathrm{L}$ of MPsexposed group, while oxidative stress index (OSI) did not recover to normal levels in all MPs-exposed groups. This may be explained by either the inability of animal tissues to eliminate microplastics or the capability to regain after recovery period (Ribeiro et al. 2017). Moreover, Paul-Pont et al. (2016) observed that after the elimination period, some antioxidant enzymes still significantly highly reflected the need for a greater capability to neutralize free radicals.

\section{Conclusion}

Microplastics exposure caused alterations in the antioxidants biomarkers (SOD, CAT, and TAC), DNA damage, and alteration in the muscle protein profile of tilapia early juvenile which may be regarded as a reason for fish mortality. The MPs have a dose-dependent effect.

Open Access This article is licensed under a Creative Commons Attribution 4.0 International License, which permits use, sharing, adaptation, distribution and reproduction in any medium or format, as long as you give appropriate credit to the original author(s) and the source, provide a link to the Creative Commons licence, and indicate if changes were made. The images or other third party material in this article are included in the article's Creative Commons licence, unless indicated otherwise in a credit line to the material. If material is not included in the article's Creative Commons licence and your intended use is not permitted by statutory regulation or exceeds the permitted use, you will need to obtain permission directly from the copyright holder. To view a copy of this licence, visit http://creativecommons.org/licenses/by/4.0/.

\section{References}

Aebi H (1984) Catalase in vitro. Methods Enzymol 105:121-126

Avio CG, Gorbi S, Milan M, Benedetti M, Fattorini D, d'Errico G, Pauletto M, Bargelloni L, Regoli F (2015) Pollutants bioavailability and toxicological risk from microplastics to marine mussels. Environ Pollut 198:211-222

Badaway EA, El-Serafy SS (1998) Comparative biochemical genetic studies on Clarias gariepinus from different polluted localities. Menofiya J Agr Res 23:1705-1715

Bagnyukova TV, Luzhna LI, Pogribny IP, Lushchak VI (2007) Oxidative stress and antioxidant defenses in goldfish liver in response to shortterm exposure to arsenite. Environ Mol Mutagen 48:658-665

Barboza LGA, Vieira LR, Guilhermino L (2018) Single and combined effects of microplastics and mercury on juveniles of the European seabass (Dicentrarchus labrax): changes in behavioural responses and reduction of swimming velocity and resistance time. Environ Pollut 236:1014-1019

Berber AA (2019) Genotoxic evaluation of polystyrene microplastic. Sakarya Univ J Sci 23:358-367

Brandts I, Teles M, Goncalves AP, Barreto A, Franco-Martinez L, Tvarijonaviciute A, Martins MA, Soares A, Tort L, Oliveira M (2018) Effects of nanoplastics on Mytilus galloprovincialis after individual and combined exposure with carbamazepine. Sci Total Environ 643:775-784

Bussolaro D, Wright SL, Schnell S, Schirmer K, Bury NR, Arlt VM (2019) Co-exposure to polystyrene plastic beads and polycyclic aromatic hydrocarbon contaminants in fish gill (RTgill-W1) and intestinal (RTgutGC) epithelial cells derived from rainbow trout (Oncorhynchus mykiss). Environ Pollut 248:706-714

Choi JS, Jung YJ, Hong NH, Hong SH, Park JW (2018) Toxicological effects of irregularly shaped and spherical microplastics in a marine teleost, the sheepshead minnow (Cyprinodon variegatus). Mar Pollut Bull 129:231-240

de Sá LC, Oliveira M, Ribeiro F, Rocha TL, Futter MN (2018) Studies of the effects of microplastics on aquatic organisms: what do we know and where should we focus our efforts in the future? Sci Total Environ 645:1029-1039

Ding J, Zhang S, Razanajatovo RM, Zou H, Zhu W (2018) Accumulation, tissue distribution, and biochemical effects of polystyrene microplastics in the freshwater fish red tilapia (Oreochromis niloticus). Environ Pollut 238:1-9 
Fazio F, Piccione G, Saoca C, Caputo A, Cecchini S (2015) Assessment of oxidative stress in Flathead mullet (Mugil cephalus) and Gilthead sea bream (Sparus aurata). Vet Med 60:2015-2691

Ferreira P, Fonte E, Soares ME, Carvalho F, Guilhermino L (2016) Effects of multi-stressors on juveniles of the marine fish Pomatoschistus microps: gold nanoparticles, microplastics and temperature. Aquat Toxicol 170:89-103

Frenzilli G, Nigro M, Lyons BP (2009) The comet assay for the evaluation of genotoxic impact in aquatic environments. Mutat Res 681: $80-92$

Hamed M, Soliman HAM, Osman AGM, Sayed AH (2019) Assessment the effect of exposure to microplastics in Nile Tilapia (Oreochromis niloticus) early juvenile: I. blood biomarkers. Chemosphere 228: 345-350

Harma M, Harma M, Erel O (2005) Measurement of the total antioxidant response in preeclampsia with a novel automated method. Eur J Obstet Gynecol Reprod Biol 118:47-51

Hook SE, Gallagher EP, Batley GE (2014) The role of biomarkers in the assessment of aquatic ecosystem health. Integr Environ Assess Manag 10:327-341

Jeong CB, Won EJ, Kang HM, Lee MC, Hwang DS, Hwang UK, Zhou B, Souissi S, Lee SJ, Lee JS (2016) Microplastic size-dependent toxicity, oxidative stress induction, and p-JNK and p-p38 activation in the monogonont rotifer (Brachionus koreanus). Environ Sci Technol 50:8849-8857

Jovanovic B (2017) Ingestion of microplastics by fish and its potential consequences from a physical perspective. Integr Environ Assess Manag 13:510-515

Karami A, Romano N, Galloway T, Hamzah H (2016) Virgin microplastics cause toxicity and modulate the impacts of phenanthrene on biomarker responses in African catfish (Clarias gariepinus). Environ Res 151:58-70

Katzenberger TD, Thorpe KL (2015): Assessing the impact of exposure to microplastics in fish. Evidence Report - SC120056. Environ Agency, Bristol

Koracevic D, Koracevic G, Djordjevic V, Andrejevic S, Cosic V (2001) Method for the measurement of antioxidant activity in human fluids. J Clin Pathol 54:356-361

Kurita-Ochiai T, Fukushima K, Ochiai K (1999) Lipopolysaccharide stimulates butyric acid-induced apoptosis in human peripheral blood mononuclear cells. Infect Immun 67:22-29

Laemmli UK (1970) Cleavage of structural proteins during the assembly of the head of bacteriophage T4. Nature 227:680-685

Lu Y, Zhang Y, Deng Y, Jiang W, Zhao Y, Geng J, Ding L, Ren H (2016) Uptake and accumulation of polystyrene microplastics in Zebrafish (Danio rerio) and toxic effects in liver. Environ Sci Technol 50: 4054-4060

Luis LG, Ferreira P, Fonte E, Oliveira M, Guilhermino L (2015) Does the presence of microplastics influence the acute toxicity of chromium(VI) to early juveniles of the common goby (Pomatoschistus microps)? A study with juveniles from two wild estuarine populations. Aquat Toxicol 164:163-174

Lusher A, Hollman P, Mendoza-Hill J (2017): Microplastics in fisheries and aquaculture. FAO fisheries and aquaculture technical paper (FAO) eng

Magni S, Gagne F, Andre C, Della Torre C, Auclair J, Hanana H, Parenti CC, Bonasoro F, Binelli A (2018) Evaluation of uptake and chronic toxicity of virgin polystyrene microbeads in freshwater zebra mussel Dreissena polymorpha (Mollusca: Bivalvia). Sci Total Environ 632: 778-788

Manke A, Wang L, Rojanasakul Y (2013) Mechanisms of nanoparticleinduced oxidative stress and toxicity. Biomed Res Int 2013:942916

Media Cybernetics (1993-1997). Gel documentation system, gel pro-analyzer. Gel pro-version 3

Mekkawy IAA, Mahmoud UM, Osman AG, Sayed AH (2010) Effects of ultraviolet $\mathrm{A}$ on the activity of two metabolic enzymes, DNA damage and lipid peroxidation during early developmental stages of the African catfish, Clarias gariepinus (Burchell, 1822). Fish Physiol Biochem 36:605-626

Muhammad OI, Mahmoud UM, Fazio F, Sayed AH (2018) SDS-PAGE technique as biomarker for fish toxicological studies. Toxicol Rep 5: 905-909

Nacci DE, Cayula S, Jackim E (1996) Detection of DNA damage in individual cells from marine organisms using the single cell gel assay. Aquat Toxicol 35:197-210

Nishikimi M, Appaji N, Yagi K (1972) The occurrence of superoxide anion in the reaction of reduced phenazine methosulfate and molecular oxygen. Biochem Biophys Res Commun 46:849-854

Ohkawa H, Ohishi N, Yagi K (1979) Assay for lipid peroxides in animal tissues by thiobarbituric acid reaction. Anal Biochem 95:351-358

Oliveira P, Barboza LGA, Branco V, Figueiredo N, Carvalho C, Guilhermino L (2018) Effects of microplastics and mercury in the freshwater bivalve Corbicula fluminea (Müller, 1774) filtration rate, biochemical biomarkers and mercury bioconcentration. Ecotoxicol Environ Saf 164:155-163

Paruruckumani PS, Maharajan A, Ganapiriya V, Narayanaswamy Y, Jeyasekar RR (2015a) Surface ultrastructural changes in the gill and liver tissue of asian sea bass Lates calcarifer (Bloch) exposed to copper. Biol Trace Elem Res 168:500-507

Paruruckumani PS, Maharajan A, Seema P, Fazildheen M, Ganapiriya V, Kumarasamy P (2015b) Characterization of protein profile in the Asian sea bass, Lates calcarifer (Bloch) exposed to copper. Inter J Fish and Aqua Stu 2:409-415

Patterson DSP (1976) Structure metabolism and toxicity of aflatoxin cab. Nutr Diet (suppl.2) 71-78

Paul-Pont I, Lacroix C, Gonzalez Fernandez C, Hegaret H, Lambert C, Le Goic N, Frere L, Cassone AL, Sussarellu R, Fabioux C, Guyomarch J, Albentosa M, Huvet A, Soudant P (2016) Exposure of marine mussels Mytilus spp. to polystyrene microplastics: toxicity and influence on fluoranthene bioaccumulation. Environ Pollut 216:724 737

Pittura L, Avio CG, Giuliani ME, d'Errico G, Keiter SH, Cormier B, Gorbi S, Regoli F (2018): Microplastics as vehicles of environmental PAHs to marine organisms: combined chemical and physical hazards to the Mediterranean mussels, Mytilus galloprovincialis. Front Marine Sci 5

Prinz N, Korez Š (2020): Understanding how microplastics affect marine biota on the cellular level is important for assessing ecosystem function: a review. In: Jungblut S, Liebich V, Bode-Dalby M (Editors), YOUMARES 9 - the oceans: our research, our future: proceedings of the 2018 conference for YOUng MArine RESearcher in Oldenburg, Germany. Springer International Publishing, Cham, pp. $101-120$

Qiao R, Sheng C, Lu Y, Zhang Y, Ren H, Lemos B (2019) Microplastics induce intestinal inflammation, oxidative stress, and disorders of metabolome and microbiome in zebrafish. Sci Total Environ 662: 246-253

Qu H, Ma R, Wang B, Yang J, Duan L, Yu G (2019) Enantiospecific toxicity, distribution and bioaccumulation of chiral antidepressant venlafaxine and its metabolite in loach (Misgurnus anguillicaudatus) co-exposed to microplastic and the drugs. J Hazard Mater 370:203211

Revel M, Lagarde F, Perrein-Ettajani H, Bruneau M, Akcha F, Sussarellu R, Rouxel J, Costil K, Decottignies P, Cognie B, Châtel A, Mouneyrac C (2019): Tissue-specific biomarker responses in the blue mussel Mytilus spp exposed to a mixture of microplastics at environmentally relevant concentrations. Front Environ Sci 7

Ribeiro F, Garcia AR, Pereira BP, Fonseca M, Mestre NC, Fonseca TG, Ilharco LM, Bebianno MJ (2017) Microplastics effects in Scrobicularia plana. Mar Pollut Bull 122:379-391 
Sayed AH, Abu Khalil SN (2016) Oxidative stress induction in monosex nile tilapia (Oreochromis niloticus, Linnaeus, 1758a): a field study on the side effects of methyltestosterone. J Aquac Res Dev 07:3

Sayed AH, Abul Khalil SN (2016) Oxidative stress induction in monosex nile tilapia (Oreochromis niloticus, Linnaeus, 1758b): a field study on the side effects of methyltestosterone. J Aquac Res Development 07:3

Sayed AH, Soliman HAM (2018) Modulatory effects of green tea extract against the hepatotoxic effects of 4-nonylphenol in catfish (Clarias gariepinus). Ecotoxicol Environ Saf 149:159-165

Sharaf-Eldeen K, Abdel-Hamid N-A (2002) Sublethal effects of copper sulfate, malathion and paraquat on protein pattern of Oreochromis niloticus. Egypt J Aquat Biol Fish 6:167-182

Soliman HAM (2017) Protein analysis and heavy metals accumulation in muscles of wild and farmed Nile Tilapia (Oreochromis niloticus). Environ Res 20:1-10

Soliman HAM, Hamed M, Lee JS, Sayed AH (2019) Protective effects of a novel pyrazolecarboxamide derivative against lead nitrate induced oxidative stress and DNA damage in Clarias gariepinus. Environ Pollut 247:678-684

SPSS (1998): SPSS for windows. SPSS Inc, Headquarters, Chicago
Sureda A, Box A, Enseñat M, Alou E, Tauler P, Deudero S, Pons A (2006) Enzymatic antioxidant response of a labrid fish (Coris julis) liver to environmental aulerpenyne. Comp Biochem Physiol C Toxicol Pharmacol 144:191-196

Tripathi G, Shukla SP (1990) Malate and lactate dehydrogenases of a freshwater catfish: impact of endosulfan. Biomed Environ Sci 3: $52-64$

Wan Z, Wang C, Zhou J, Shen M, Wang X, Fu Z, Jin Y (2019) Effects of polystyrene microplastics on the composition of the microbiome and metabolism in larval zebrafish. Chemosphere 217:646-658

Yu P, Liu Z, Wu D, Chen M, Lv W, Zhao Y (2018) Accumulation of polystyrene microplastics in juvenile Eriocheir sinensis and oxidative stress effects in the liver. Aquat Toxicol 200:28-36

Zhang S, Ding J, Razanajatovo M, Jiang H, Zou H, Zhu W (2018) Interactive effects of polystyrene microplastics and roxithromycin on bioaccumulation and biochemical status in the freshwater fish red tilapia (Oreochromis niloticus). Sci Total Environ 648:1431-1439

Publisher's note Springer Nature remains neutral with regard to jurisdictional claims in published maps and institutional affiliations. 